Maurer School of Law: Indiana University

Digital Repository @ Maurer Law

1983

\title{
The Legal/Extra-Legal Controversy: Judicial Decisions in Pretrial Release
}

Ilene H. Nagel

Indiana University School of Law

Follow this and additional works at: https://www.repository.law.indiana.edu/facpub

Part of the Criminal Procedure Commons, Criminology and Criminal Justice Commons, and the Judges Commons

\section{Recommended Citation}

Nagel, Ilene H., "The Legal/Extra-Legal Controversy: Judicial Decisions in Pretrial Release" (1983). Articles by Maurer Faculty. 2078.

https://www.repository.law.indiana.edu/facpub/2078

This Article is brought to you for free and open access by the Faculty Scholarship at Digital Repository @ Maurer Law. It has been accepted for inclusion in Articles by Maurer Faculty by an authorized administrator of Digital Repository @ Maurer Law. For more information, please contact rvaughan@indiana.edu. 


\title{
THE LEGAL/EXTRA-LEGAL CONTROVERSY: JUDICIAL DECISIONS IN PRETRIAL RELEASE
}

\author{
ILENE H. NAGEL*
}

\begin{abstract}
This study analyzes data for state criminal defendants prosecuted in New York to determine the bases upon which judges make pretrial release decisions for these defendants. Treating statutory law as defining the category of legal variables, it finds legal factors substantially affect decisions about whether to release a defendant on recognizance, the amount of bail required, and whether to offer a defendant a cash alternative to a surety bond. The impact of these factors varies, however, depending upon the particular decision being made. Factors not prescribed in the statute-extra-legal factors-are also found to affect these pretrial release decisions. Their impact, too, is decision context specific. Among the extra-legal factors that affect pretrial release decisions, the effects of status characteristics of the defendant pale in comparison to the effects of bench bias and measures of the defendant's dangerousness.
\end{abstract}

\section{INTRODUCTION}

For nearly six decades both social scientists and lawyers have been preoccupied with the search for evidence that law in theory differs dramatically from the law in action. For social scientists in general and criminologists especially this search has commonly focused on amassing data to test the hypothesis that extra-legal considerations, such as race, class, and ethnicity, account for substantial variation in the application of laws and sanctions. Some researchers have interpreted their data to mean that the legal prescriptions that supposedly guide decision-making are of distinctly secondary importance.

- Support for this research was provided by a Yale Law School Daniel and Florence Guggenheim Fellowship to the author, by the Indiana University School of Law, and by the Rockefeller Foundation Scholar-in-Residence program in Bellagio, Italy. Special thanks are extended to Richard Berk, Lawrence Friedman, Daniel J. Freed, John Hagan, Sheldon Plager, Peter Rossi, and David Thomas for their comments on earlier drafts. Thanks are extended to Liese Sherwood-Fabre and Kathy Ross for assistance with data analysis. The manuscript benefited considerably from the substantive and editorial comments suggested by Richard Lempert, Editor of the Law \& Society Review. Additional analyses to which I refer can be obtained from me by written request. 
In 1974, Hagan turned his attention to the claimed priority of extra-legal factors in criminal sentencing. Reanalyzing data drawn from twenty sentencing studies, Hagan concluded:

... while there may be evidence of differential sentencing, knowledge of extra-legal offender characteristics contributes relatively little to our ability to predict judicial dispositions (1974: 379).

McBarnet (1981), reviewing claims for the priority of extralegal factors, was prompted to write:

... Explicitly or implicitly the question underlying sociological analysis of the criminal justice process always seems to be concerned with why the people who routinely operate the law also routinely depart from the principles of justice ... violating the principle of equality before the law by being more likely to arrest, convict, or sentence with greater severity lowerrather than middle- or upper-class people, blacks, rather than whites. . . . One study after another shows up class, race, and sex prejudices ... [But] what is barely touched on is the nature and role of the law itself . . . (1981: 3-4).

"Law in action" research has almost entirely lost sight of the most obvious dimension to consider-the law itself:

... Ironically ... some vague notion of "the law" is usually there as a background assumption, as a vague standard from which the law enforcers under study are assumed to deviate. . . . [However, while] the "law in action" is scrutinized ... . what the "law in the books" actually says is simply assumed ... (McBarnet, 1981: 5).

The criticism is a fair one. The claimed priority of extralegal factors has clearly, and properly, become controversial. In visiting the legal/extra-legal controversy, I wish to emphasize an important point of departure from prior attempts to examine the issue. "Extra-legal" in this study is not considered synonymous with "illegal," "inappropriate," or "socially unjust." It is defined as that which is "extra" to the law, i.e., not specifically prescribed in the relevant statutory law. I do not mean by this definition to imply that unless a factor is specifically prescribed by statute it can never be part of the law. I do, however, claim that this is a useful starting point for those who seek to ground the legal/extra-legal debate in a context that is sensitive to the actual prescriptions of written law. By beginning in this way, I may be better able to untangle the morass of that heretofore unspecified residual category which has passed for extra-legal; and I may be better able to gain insight into the effects of indisputably legal variables. 
This research focuses on pretrial release decisions in criminal cases. New York, the jurisdiction studied, has a statute that specifies the factors a court may appropriately consider in deciding whether to grant bail and the amount at which granted bail should be set. I examine the legal/extralegal controversy in this context by comparing the influence of those factors prescribed in the Bail Statute with the influence of those not prescribed. The comparisons are broken down by stages of the pretrial release decision so that I can explore the relative influence of legal and extra-legal variables on different kinds of decisions.

I expect that more than law in theory dictates law in action. I hope that this examination of different aspects of bail setting will reveal differences in the relative influence of different legal and extra-legal factors, for the interesting task is not to spot a gap between the law on the books and the law in action but to understand why legal rules may on some occasions have considerable influence and on other occasions be relatively inconsequential.

Social scientists, often assuming a gap between law in theory and law in action, have concentrated their efforts on searching for discriminatory practices on the part of those who administer the law. (See, for example, Lemert, 1951; Becker, 1963; Kitsuse and Cicourel, 1963; Quinney, 1970; Burke and Turk, 1975; Chiricos and Waldo, 1975; Hagan, 1975; Swigert and Farrell, 1977; Bernstein et al., 1977a; Bernstein et al., 1977b; Lizotte, 1978; LaFree, 1980; Unnever et al., 1980; Nagel and Hagan, 1982a; Wheeler et al., 1982; Hagan and Nagel, 1982.) The implicit message is that if discrimination could be eliminated, the gap would disappear. Legal realists have recognized that the gap is structural. General rules of law cannot dictate specific outcomes; discretion must always intervene. Yet the question remains: Does discretion operate in discriminatory ways? If so, is it because decision-makers violate the principles of equality before the law, or is it because applicable rules of law have discriminatory implications?

To address these issues, one must look at the relative contributions of formal written law and extra-legal factors to outcomes and the ways in which their relative influence is context dependent. One must also look at the outcomes themselves. If class-based discrimination is apparent, the task is to determine whether observed patterns are attributable to formal written law, extra-legal factors, or both. 
The study of pretrial release decisions is for several reasons particularly well suited to an exploration of the issues just identified. First, and most important, the pretrial release decision is the only major criminal court processing decision for which there is a formal set of statutorily prescribed guidelines specifying particular factors to be considered in the making of the decision. In New York the Bail Statute states the following:

To the extent that the issuance of an order of recognizance or bail and the terms thereof are matters of discretion .... an application is determined on the basis of the following factors and criteria...

a) With respect to any principal, the court must consider the kind and degree of control or restriction that is necessary to secure his court attendance when required. In determining that matter, the court must, on the basis of available information, consider and take into account:

(i) The principal's character, reputation, habits and mental condition; and

(ii) His employment and financial resources; and

(iii) His family ties and the length of his residence if any in the community; and

(iv) His criminal record if any; and

(v) His previous record if any in responding to his court appearances when required or with respect to flight to avoid criminal prosecution; and

(vi) If he is a defendant, the weight of the evidence against him in the pending criminal action and any other factor indicating probability or improbability of conviction; or, in the case of an application for bail or recognizance pending appeal, the merit or lack of merit to the appeal; and

(vii) If he is a defendant, the sentence which may be or has been imposed upon conviction (N.Y.S. Rules of Criminal Procedure, 510.30 § 2).

Because the statute specifically lists the factors to be considered in determining conditions of release, one can come closer in this setting than in most others to ascertaining whether the statutory law has an effect on the outcome decisions. Furthermore, one can compare the effect of factors prescribed in the statute, i.e., legal factors, to those not prescribed, i.e., extra-legal factors, and can identify the conditions under which the effects of these legal and extra- 
legal factors vary. ${ }^{1}$

Second, the pretrial release decision is generally a threetiered process, each decision being a refinement of the preceding one. The first decision is whether to release the defendant on recognizance, i.e., on an unsecured promise by the defendant to be in court for scheduled appearances. ${ }^{2}$ If the decision is made not to release the defendant on recognizance, then, absent a judgment that the defendant is unbailable, ${ }^{3}$ the next decision concerns the dollar amount of the required surety bond.4 Finally, some defendants are given the option of posting a cash alternative to the surety bond, ordinarily in the amount of 10 percent of the surety figure. The cash alternative option increases the likelihood that a defendant will meet the terms for release.

1 As noted earlier, to classify only those factors prescribed for consideration in the statute as the "legal factors" is to narrowly conceptualize the word "legal." Judicial consideration of factors not specifically prescribed may be legal as well, for the statute does not say that the court must not consider any factor not here mentioned. However, as a first step in addressing the legal/extra-legal controversy, it is essential to determine whether those factors which the statute says a court must consider have an impact. Once non-statutory factors that have an impact are identified, one can engage in further research and analysis to determine whether these factors cannot legally guide judicial discretion.

2 According to my interviews and observations, the first question judges address is the question of whether a defendant should be released on recognizance or whether some restrictive terms will be necessary to condition the release of the defendant. Moreover, it often appeared as if, subsequent to the decision not to release a defendant on recognizance, the judge wrestled not only with the question of an amount of bail to require but also with the issue of whether bail should be set higher than the defendant could meet so as to detain the defendant preventively.

3 In accordance with People ex rel. Shapiro v. Keeper of City Prison et al. and People v. Melville, a reading of New York case law suggests that it is appropriate to deny bail under certain circumstances. These cases are consistent with the Supreme Court's holding in Carlson v. Landon that there is no constitutional right to bail, and a court is not obligated to release a defendant on bail. The eighth amendment to the United States Constitution does, however, specify that when bail is set, it cannot be set in an unreasonably high amount and must not be set as a punitive measure. In People ex rel. Shaw v. Lombard the court held "There are three situations which affect the pretrial release of a defendant: (1) the necessity to insure the defendant's response to the processes of the court, (2) the necessity to protect potential witnesses from the defendant and (3) the necessity to protect the community from a dangerous defendant." There is no debate on the fact that the purpose of requiring the defendant to post bail after his arrest is to insure his appearance in court. The court, however, does hold that "although there is no statutory authority in New York to detain in order to protect potential witnesses from a defendant, case law has recognized the denial of bail in situations where the defendant would present a danger to potential witnesses if permitted to remain at liberty" (see, for example, People ex rel. Klein v. Krueger). The court concludes that under certain circumstances, a defendant can be denied bail.

4 A request for a surety bond requires the defendant to have a bail bondsman post bail with the court for the defendant. Regardless of appearance, the bondsman receives a fee, usually $10 \%$ of the amount of the bail bond. 
The advantage of studying a three-tiered decision is that it allows one to attend to the possibility that as a legal judgment is successively refined, different factors may affect decisions. In other words, decision stages are a source of contextual variation. Nothing in the statute suggests that the specified criteria (legal factors) are not meant by the legislature to apply in the same way to the three sequentially occurring pretrial decisions, but the complexity of the issues and the consequences that might ensue from different outcomes at different stages may vary substantially.

Third, the pretrial release decision has been found to affect subsequent criminal justice processing decisions (e.g., Ares et al., 1963; Landes, 1974; Bernstein et al., 1977a; Hagan et al., 1980). Thus, the study of bail decisions is interesting both in its own right and as an aid to understanding how defendants come to be differentially situated at later stages of their cases.

Fourth, the bail statute is interesting in that the enacted legislation is in some respects inconsistent with public sentiment. The New York Bail Statute does not authorize a judge to deny bail or to set high bail in order to prevent defendants from engaging in future criminal activity. The possibility of preventive pretrial detention was considered by the state legislature and rejected. Legal scholars are divided on the issue, but the public is generally presumed to support the concept, albeit perhaps only for cases involving violent crime. ${ }^{5}$ (Federal Bail Procedures, 1964; 1981; Thomas, 1976; Carbone, 1977; American Bar Association, 1978; Kennedy, 1979). A study of the application of the Bail Statute provides one opportunity to examine whether "the formal law," as measured by statutorily prescribed considerations, is adhered to when the risk of public criticism is substantial. To the extent that public pressure attenuates conformity with the written law, a lack of conformity might be explained as stemming partially from a law that fails to reflect the moral sentiments of the community.

Finally, every part of the legal system has its own special procedures and its own way of making rules and decisions. Each part responds to the cluster of forces that impinge on it in

5 A review of case law suggests that judges too may have mixed views of preventive detention. In People ex rel. Shapiro v. Keeper of City Prison et al. the court held that New York's constitution, by prohibiting excessive bail, did not accord to all defendants an undeniable right to bail, but rather forbade only excessive bail. Thus, in certain circumstances, the denial of bail in non-capital felony cases was held to be proper. In People v. Melville, in a major departure from previous cases, Judge Lang held that pretrial detention "for the safety of the community through the denial of bail .... is constitutionally justifiable in extraordinary cases." 
a different way (Friedman, 1977). This means that the application of legal rules will be affected by the task that the legal decision-maker confronts. Thus, while the study of pretrial release decisions complements studies of arrest (e.g., Black, 1971), prosecution (e.g., Miller, 1970), plea bargains (e.g., Sudnow, 1965; Bernstein et al., 1977b), and sentencing (e.g., Wolfgang and Riedel, 1973; Chiricos and Waldo, 1975), it is distinctive insofar as it is a decision that occurs in a separate context and is subject to separate concerns, pressures, and considerations.

\section{RESEARCH ISSUES}

My analysis focuses on four issues. The data do not resolve any of the issues raised here, but they do provide a starting point for rethinking and reconceptualizing the legal/extra-legal controversy.

First, I ask whether the formal law, as embodied in those factors that are statutorily prescribed, affects pretrial release outcomes. To address this question, indicators of some of the seven items (i-vii) that the Bail Statute instructs judges to consider are examined. It is not necessarily illegal to consider factors that are not statutorily prescribed, but if mandated factors are not considered, there is a failure of legality even if the final decision does not reflect impermissible considerations.

Second, to allow for the possibility of contextual variation, I examine the degree to which the impact of these statutorily prescribed factors is consistent across the three stages of decision-making for pretrial release.

Third, to the extent that the legally prescribed factors do not account for all of the variation in pretrial release outcomes, I attempt to determine whether factors not mentioned in the statute (extra-legal factors) affect the outcomes.

Finally, I ask whether the emphasis in the literature on class, race, and sex as the predominant extra-legal influences is borne out by these data, or whether some of the effects attributable to factors not prescribed by law are extra-legal without being clearly illegal or unjust. To the extent that we can identify which extra-legal variables have an impact, we can better understand the bases upon which pretrial decisions are made and the relationship between formal law and other factors that affect these decisions. 


\section{THE SAMPLE}

The sample used in this study consists of all those cases $(\mathrm{N}=5594)$ first arraigned in criminal court in one borough of the city of New York between December, 1974, and March, 1975.6 This group includes both accused felons and accused misdemeanants. Defendants whose cases were finally disposed of at their first court presentation were excluded because no pretrial release decisions were made for them. Cases not admitted to bail because the defendants were remanded to custody are also excluded. Where the presumption of guilt is great, and the potential danger to society extraordinary, defendants may as a matter of New York law be denied the right to bail. ${ }^{7}$

\section{DATA}

For each of the 5594 defendants, information was recorded concerning prior criminal records (no prior arrests, arrests but no convictions, convictions for misdemeanors or violations, or convictions for felonies ${ }^{8}$ ), the severity of the most serious crime charged (following the nine-point classification of New York's Penal Code), race/ethnicity (i.e., black, white, Hispanic $^{9}$ ), highest school grade completed, age, sex, primary speaking language (i.e., Spanish, English ${ }^{10}$ ), and the Pretrial

6 Arraignment court, the setting for this research, is a lower criminal court. All criminal defendants, regardless of the severity of their charge, were arraigned in this court.

7 It is important to note that while the court has held that the denial of bail is appropriate in cases where the potential danger to society is extraordinary, or there is a demonstrable need to protect witnesses, the court has never held that it is appropriate to set high bail to diminish the probability of release or to accomplish the purpose of preventive detention. (See People ex rel. Shapiro v. Keeper of City Prison et al. and People v. Melville.)

8 I distinguish between convictions for felony offenses on the one hand and convictions for lesser offenses or arrests but no convictions on the other for two reasons: (1) prior research (e.g., Bernstein et al., 1977b) finds responses differ according to the nature of the prior record, and (2) my observations led me to believe that judges and prosecutors treat records of felony convictions more seriously than they do records of misdemeanor convictions. I did not further refine the categories into level of felony conviction (e.g., A felony versus $D$ felony) because the court records were not so refined as to permit this kind of classification.

9 Hispanic refers to persons with Spanish surnames, e.g., Gonzalez, Huerrera. I divide race/ethnicity into three categories in order to be able to determine whether the Hispanic population (largely of Puerto Rican origin) is treated differently from the blacks or whites.

10 A separate category is made for persons whose primary language is Spanish because my observations suggested that those who are dependent upon translators created special problems for the courts. One possible response would be to discriminate against those who did not speak English. It should be noted that the correlation between those whose surname is Hispanic and those whose primary language is Spanish is low enough that this additional coded variable did not create problems of multicollinearity. 
Services Agency's recommendation regarding release on recognizance (ROR). ${ }^{11}$ The criminal record data came from state files; other information came from reports prepared by a Pretrial Services Agency which interviewed defendants within 24 hours of their arrest and, in the case of severity, from court files. Measures of prior record, charge severity, and ROR recommendation are included because they may be considered "legal" variables. Variables that capture the race/ethnicity, age, sex, education, and primary language of the defendant are important because the thesis that such extra-legal characteristics improperly influence court action is at the heart of the legal/extra-legal debate. Quinney (1970: 140) states this thesis as follows:

... judicial decisions are not made uniformly. Decisions are made according to a host of extra-legal factors, including the age of the offender, his race and social class ...

Reiss (1974), drawing on the work of Schrag (1971), summarizes this position:

... A growing body of evidence ... on the distributive property of criminal justice ... demonstrates that there is much de facto discrimination. The poor and the minorities .... are likely to be sanctioned more severely, and to be denied their rights and the full opportunity to defend their interests (Reiss, 1974: 694).

Information was also coded on three variables that might reflect the degree to which a defendant is likely to be perceived as potentially dangerous. These indicate whether: (1) the defendant was being prosecuted for possession of a dangerous weapon; (2) the most serious charge for which the defendant

11 During the time at which these data were collected, there was a Pretrial Services Agency whose primary purpose was to collect information on defendants, especially on their community ties, so as to be able to make recommendations for release to the judge during arraignment proceedings. Pretrial Services agents interviewed defendants immediately following their arrest. Every attempt was made to verify the information received from the defendant prior to making a decision to recommend, or not recommend, release at arraignment. The recommendation of the Pretrial Services agents was in accordance with the only legitimate purpose of bail, which is to ensure a defendant's appearance in court. The Pretrial Agency made one of three recommendations for each defendant: (1) recommended for release on recognizance-demographic data verifled; (2) recommended for release on recognizance-demographic data not verified; (3) no recommendation. After interviewing Pretrial agents, I opted to collapse the first two categories into one category-recommended for release on recognizance. This category, for purposes of these analyses, was compared to those for whom no recommendation for release on recognizance was made. For a discussion of the relationship between this recommendation and the defendant's community ties, see the text accompanying note 23 infra. 
was being prosecuted is classified as a violent crime; ${ }^{12}$ and (3) one of the charged offenses was resisting arrest. ${ }^{13}$ Attention to dangerousness is not prescribed by the New York Bail Statute, but some case law allows the denial of bail when there appears to be an extraordinary potential for danger (see People v. Melville). However, the instances in which courts might properly attend to dangerousness in deciding whether to set bail are exceedingly rare, and the New York courts have never held that danger may affect the amount at which bail is set or the mode of release (People ex rel. Schweizer v. Welch; People v. Torres).

Information was also collected on the pendency of other charges at the time of this arraignment. In most instances, the presence of an "open case" indicates that the crime for which pretrial release data were collected was committed while the accused was free pending trial for some other offense. It seems likely that those with open charges will fare poorly at this arraignment since they will be thought to have abused a prior opportunity for freedom. Depending upon one's interpretation of the statutory language, ${ }^{14}$ this may be an example of an extralegal variable that can affect the pretrial outcome decisions without implying invidious discrimination.

Finally, I have information on a variable not heretofore examined in empirical research on pretrial release decisions: the identity of the judge presiding at the arraignment hearing. Since my interest is not in particular judges but rather in the variation of decisions across judges, the data on judges are reported using a code that does not permit individual identification.

Information on each of the above variables is presented to the judge at the arraignment proceeding. These are not, however, the only variables about which judges are sometimes

12 A review of the penal law categories for the state of New York led me to classify offenses into "violent" and "less violent" crimes. Those classified as violent include: first, second, and third degree assault; homicide, murder, manslaughter; first, second, and third degree rape; first, second, and third degree sexual abuse; first, second, third, and fourth degree arson; and first, second, and third degree robbery. With the exception of arson, these are all crimes traditionally categorized as involving personal violence. I included arson as well because I believe that it is more like the crimes of personal violence than it is like the traditional property offenses.

13 This charge may also indicate a special interest by the police in high or no bail, either to punish the defendant or to dissuade the fling of a civil suit. Whatever interpretation one puts on it, it is extra-legal.

14 Unless one believes that the existence of an open case is evidence of a defendant's character or reputation, specifled as legal in item $i$ of the statute, the fact that a defendant has an open case should be considered an extra-legal variable. 
informed. On an unsystematic basis, often as a result of speculation by the defense attorney, judges may be informed of such things as the defendant's weekly salary, family situation (e.g., number of dependents), and welfare status. While such information might properly influence pretrial release decisions, the inconsistency with which information of this type was preserved in official records prevented me from including variables capturing such information in the analyses. I do not believe that this constitutes a substantial gap because courts did not routinely have information of this sort and when they did it was often presented in a haphazard and unverifiable fashion. 15

I have no data that measure the weight of the evidence, a potentially important legal variable. However, my six months of observations of arraignment procedures indicate that judges similarly do not have, or fail to consider, information pertaining to the weight of the evidence. This is largely because of the brief period of time given to arraignment proceedings. Pretrial Services agents also have no information on evidence. This means, however, that my findings will not necessarily generalize to jurisdictions that make evidentiary or other information I lack routinely available at the arraignment stage.

In addition to the archival record data noted above, qualitative data were collected through my observations of arraignment procedures over a period of six months. During the observations, I reviewed the "court papers"16 immediately following their presentation to the presiding judge. This process was possible because I was seated alongside the judge, on the bench, before and during arraignment procedures. While no formal analysis of these observational data was done, my observations, as well as information gleaned in conversations with the judges about the "whys" of their decisions, helped guide the design of the analysis and influenced my interpretations of the findings.

15 In an analysis of the determinants of pretrial outcomes for defendants prosecuted in federal rather than state courts, I find a defendant's earnings have no effect on the type of pretrial release condition. Married defendants and those on welfare, however, are more likely to be asked to meet less restrictive conditions in order to be released (see Stryker et al., 1983).

16 Court papers are those materials presented to the judicial officer, for example, the police report, the report of prior arrests and convictions, the report of the charge against the defendant filed by the prosecutor, and the recommendation of the Pretrial Services Agency. 


\section{ANALYSIS}

The data are analyzed by means of dummy variable regression procedures. Table 1 lists all independent and dependent variables and tells how each was coded.17 The correlation matrix of the independent variables was reviewed to check for serious problems of multicollinearity before any analyses were done. No problems of multicollinearity were noted. ${ }^{18}$

Table 1. Variables: Scaling, Notation, and Frequencies

\begin{tabular}{|c|c|c|c|}
\hline Notation & Variable & Scale & Frequency \\
\hline \multirow[t]{2}{*}{$\mathbf{Y}_{1}$} & $\begin{array}{l}\text { Decision at First } \\
\text { Arraignment }\end{array}$ & $\begin{array}{l}\text { Not Released on } \\
\text { Recognizance (0) }\end{array}$ & 43.6 \\
\hline & & $\begin{array}{l}\text { Released on } \\
\quad \text { Recognizance (1) }\end{array}$ & 56.4 \\
\hline \multirow[t]{2}{*}{$\mathrm{Y}_{2}$} & $\begin{array}{l}\text { For Defendants not } \\
\text { ROR'd, Amount of } \\
\text { Bail Set }\end{array}$ & $\begin{array}{l}\text { Logarithm of Bail } \\
\text { Amount (Interval) }\end{array}$ & $\begin{array}{l}\mathrm{X}=2.93 \\
\mathrm{~s} . \mathrm{d}=.59\end{array}$ \\
\hline & & Actual Bail (in \$) & $\begin{array}{l}X=\$ 2096.38 \\
\text { s.d. }=6189.95\end{array}$ \\
\hline \multirow[t]{2}{*}{$\mathrm{Y}_{\mathbf{3}}$} & For Defendants for & No Cash Alternative (0) & 53.3 \\
\hline & $\begin{array}{l}\text { the Cash Alternative } \\
\text { Option }\end{array}$ & Cash Alternative (1) & 46.7 \\
\hline \multirow[t]{2}{*}{$\mathrm{x}_{1}$} & $\begin{array}{l}\text { Pretrial Services Agency } \\
\text { Recommendation for } \\
\text { ROR }\end{array}$ & $\begin{array}{l}\text { Not Recommended for } \\
\text { ROR }(-1)\end{array}$ & 35.9 \\
\hline & & $\begin{array}{l}\text { Recommended for ROR } \\
\text { (1) }\end{array}$ & 64.1 \\
\hline $\mathbf{x}_{2}$ & Defendant's Age & (Interval) & $\begin{array}{l}X=27.10 \\
\text { s.d. }=9.4\end{array}$ \\
\hline \multirow[t]{2}{*}{$\mathbf{x}_{\mathbf{3}}$} & Defendant's Sex & Female $(-1)$ & 10.5 \\
\hline & & Male (1) & 89.5 \\
\hline$x_{4}$ & $\begin{array}{l}\text { Defendant's } \\
\text { Race/Ethnicity I }\end{array}$ & $\begin{array}{l}\text { Hispanic (-1) } \\
\text { Black (0) } \\
\text { White (1) } \\
\end{array}$ & $\begin{array}{l}43.3 \\
44.4 \\
12.3 \\
\end{array}$ \\
\hline$x_{5}$ & $\begin{array}{l}\text { Defendant's } \\
\text { Race/Ethnicity II }\end{array}$ & $\begin{array}{l}\text { Hispanic }(-1) \\
\text { White (0) } \\
\text { Black (1) } \\
\end{array}$ & $\begin{array}{l}43.3 \\
12.3 \\
44.4 \\
\end{array}$ \\
\hline$x_{6}$ & $\begin{array}{l}\text { Defendant's Primary } \\
\text { Language }\end{array}$ & $\begin{array}{l}\text { English (-1) } \\
\text { Spanish (1) }\end{array}$ & $\begin{array}{l}87.8 \\
12.2\end{array}$ \\
\hline $\mathrm{x}_{7}$ & $\begin{array}{l}\text { Highest Grade in School } \\
\text { Defendant Completed }\end{array}$ & (Interval) & $\begin{array}{l}X=10.05 \\
\text { s.d. }=1.89\end{array}$ \\
\hline
\end{tabular}

17 Nominal variables are effect coded in accordance with the arguments of Kerlinger and Pedhazur (1973) that effect coding, comparing each category to the mean of the other categories rather than to an excluded category, is preferable in exploratory research.

18 With the exception of the correlation between violent offense and charge severity, the only correlations that are over .4 are those between categories of the same variable. These correlations do not reflect multicollinearity; rather they are an inescapable byproduct of effect coding. 


\begin{tabular}{|c|c|c|c|}
\hline Notation & Variable & Scale & Frequency \\
\hline $\mathbf{x}_{\mathbf{8}}$ & $\begin{array}{l}\text { Severity (According to } \\
\text { New York Penal } \\
\text { Code) of First } \\
\text { Presentation Charge } \\
\text { (Charge Prosecuted) }\end{array}$ & $\begin{array}{l}\text { Violation (1) } \\
\text { Unclassified } \\
\text { Misdemeanor (2) } \\
\text { B Misdemeanor (3) } \\
\text { A Misdemeanor (4) } \\
\text { E Felony (5) } \\
\text { D Felony (6) } \\
\text { C Felony (7) } \\
\text { B Felony (8) } \\
\text { A Felony (9) }\end{array}$ & $\begin{array}{l}11.5 \\
0.0 \\
\\
3.6 \\
21.0 \\
12.2 \\
27.5 \\
10.9 \\
10.9 \\
2.4\end{array}$ \\
\hline \multirow[t]{3}{*}{$X_{9}$} & Prior Criminal Record I & No Prior Arrests $(-1)$ & 26.0 \\
\hline & & $\begin{array}{l}\text { Arrests with No } \\
\text { Convictions, Arrests } \\
\text { with Misdemeanor } \\
\text { Convictions (0) }\end{array}$ & 66.3 \\
\hline & & $\begin{array}{l}\text { Arrests with Felony } \\
\text { Convictions (1) }\end{array}$ & 7.7 \\
\hline \multirow[t]{3}{*}{$\mathbf{x}_{10}$} & Prior Criminal Record II & No Prior Arrests $(-1)$ & 26.0 \\
\hline & & $\begin{array}{l}\text { Arrests with } \\
\text { Misdemeanor or } \\
\text { Felony Convictions } \\
\text { (0) }\end{array}$ & 22.1 \\
\hline & & $\begin{array}{l}\text { Arrests with No } \\
\text { Convictions (1) }\end{array}$ & 51.9 \\
\hline \multirow[t]{3}{*}{$\mathbf{x}_{11}$} & Prior Criminal Record & No Prior Arrests $(-1)$ & 26.0 \\
\hline & & $\begin{array}{l}\text { Arrests but No } \\
\text { Convictions or Felony } \\
\text { Convictions (0) }\end{array}$ & 59.7 \\
\hline & & $\begin{array}{l}\text { Arrests with } \\
\text { Misdemeanor } \\
\text { Convictions (1) }\end{array}$ & 14.4 \\
\hline \multirow[t]{2}{*}{$\mathbf{X}_{12}$} & Defendant's Charges & No $(-1)$ & 97.7 \\
\hline & a Dangerous Weapon & Yes (1) & 2.3 \\
\hline \multirow[t]{2}{*}{$\mathbf{x}_{13}$} & $\begin{array}{l}\text { Most Serious Charge for } \\
\text { Which Defendant Was }\end{array}$ & Non-Violent $(-1)$ & 72.1 \\
\hline & $\begin{array}{l}\text { Prosecuted is a } \\
\text { "Violent" Crime (See } \\
\text { note 12, supra) }\end{array}$ & Violent (1) & 27.9 \\
\hline \multirow[t]{2}{*}{$\mathbf{X}_{14}$} & $\begin{array}{l}\text { Defendant's Charges } \\
\text { Include Resisting }\end{array}$ & No $(-1)$ & 98.1 \\
\hline & Arrest & Yes (1) & 1.9 \\
\hline \multirow[t]{2}{*}{$\mathbf{X}_{15}$} & $\begin{array}{l}\text { In Addition to this Case, } \\
\text { the Defendant has }\end{array}$ & No Open Cases $(-1)$ & 76.4 \\
\hline & Other Pending Cases. & Open Cases (1) & 23.6 \\
\hline
\end{tabular}

$\mathrm{X}_{16}-\mathrm{X}_{25}$ Represent the ten judges who presided over pretrial decisions.

Tables 2, 3 and 4 present the results of the regression equations for the three dependent variables respectively, i.e., $Y_{1}$ whether the defendant was released on recognizance or bail was set; $Y_{2}$ the log of the amount at which bail was set if bail 
was set; ${ }^{19}$ and $Y_{3}$ whether the judicial officer offered a cash alternative at a sum below the dollar figure of the bail bond. ${ }^{20}$

For the first dependent variable, $Y_{1}$ (whether the defendant was released on recognizance or bail was set), I computed the regression equation for the total sample of 5594 defendants. $Y_{1}$ is regressed on all of the independent variables listed in Table 1. Table 2 presents the regression coefficients for only those independent variables whose effects were statistically significant at .10 or better. ${ }^{21}$

For the second dependent variable, $Y_{2}$ (the $\log$ of the amount at which bail was set), the same procedure as outlined above is followed, except that only data on those defendants who were not released on recognizance (i.e., had bail set) are included $(\mathrm{N}=2083)$.

For the third dependent variable, $Y_{3}$ (the offering of a cash alternative), the analysis is based only on data for defendants for whom bail was set $(\mathrm{N}=2083)$. As with $\mathrm{Y}_{1}$ and $\mathrm{Y}_{2}$, the cash alternative option is regressed on the set of independent variables listed in Table 1.

\section{RESULTS}

\section{A. Do Statutorily Prescribed Factors Affect Judicial Decisions About Pretrial Release?}

Despite efforts by the drafters of the Bail Statute to clearly specify legally prescribed considerations, the statutory language allows some dispute over whether any particular variable does or does not fall under one of the seven statutorily specifled criteria. For example, almost anything could be construed as a measure of a defendant's character or reputation. My many months of observation and interviews, however, lead me to believe that the participants in the process did not always assume that any information they gave was related to some specifled criterion. Instead, some information

19 In examining the distribution of bail amounts, I noted that the distribution of amounts of bail was skewed. To lessen the impact of outliers, I took the natural logarithm of the amount of bail as the dependent variable. The substantive implications of the findings do not change from what they would be had I used dollar amounts, but I cannot make statements about particular changes in the independent variables producing changes of $X$ dollars in the bail amount.

20 Cash alternative was coded as being present if the cash figure requested was lower than the bond (e.g., $\$ 2000$ bond or $\$ 200$ cash). If it was not lower (e.g., $\$ 1000$ bond or $\$ 1000$ cash), I coded the defendant as having no cash alternative.

21 Goldberger (1964) recommends this more liberal significance level in the case of dummy dichotomous dependent variables. It is particularly appropriate in exploratory research. 
would be acknowledged by almost everyone to be statutorily irrelevant, and other information was thought to relate largely or entirely to a single criterion. Without wishing to deny the inevitable subjectivity and arbitrariness of any classification, I believe the following are consistent with the statutorily (legally) prescribed considerations.

Item $i$ mandates the consideration of the defendant's character, reputation, habits, and mental condition. Apart from a judge's possible subjective judgment of the defendant's mental condition, my observations of arraignment procedures revealed that no information on these considerations was systematically presented to the court, nor was systematic inquiry made in the absence of blatant aberrational behavior. ${ }^{22}$ Since my quantitative analysis is based on recorded data, no measure of these legal dimensions was included.

Item $i i$ says the defendant's employment and financial resources should be taken into account. Specific information on these matters was not routinely presented to the court, but the court knew that the Pretrial Services Agency's recommendation for release on recognizance was based in part on the defendant's employment situation. Reliable data on financial resources were often neither presented nor the subject of judicial inquiry.

Item $i i i$ mandates the consideration of family ties and length of residence in the community. Again specific information regarding these matters was seldom presented in court, but the judges knew that family ties and community residence were among the seven factors that determined the Pretrial Services Agency's recommendation. ${ }^{23}$ Because those with substantial community ties (employment, long time

22 In six months of observation, for example, only once did I observe a discussion of a defendant's mental condition. In this particular instance, the defendant identified himself as "God's angel." His behavior in the courtroom was so substantially at odds with expectations for defendant behavior that the judge was prompted to request a psychiatric investigation. The pretrial hearing was rescheduled to follow the presentation of the psychiatric report.

23 The Pretrial Services Agency based its recommendation for release on responses to seven items: (1) length of residence; (2) phone in a residence; (3) someone is expected to accompany the defendant at arraignment (not including the complainant or the attorney); (4) family ties; (5) employment history; (6) prior felony convictions; (7) verified responses to one or more questions. Each of the items was equally weighted. Defendants with scores of four or above were recommended for release. For example, if a defendant had a phone $(+1)$, lived at his current address for $2 \frac{1}{2}$ years $(+1)$, lived with a parent or spouse $(+1)$, and was employed $(+1)$, he would be recommended for release. Any combination of positive scores totaling four resulted in a positive recommendation for release on recognizance. Importantly, a negative on any particular item, e.g., prior felony conviction, did not preclude a recommendation for release. 
residence, and close family relationships) were more likely to be recommended for ROR, while those with no community ties found it very difficult to secure an ROR recommendation, I treat the recommendation of the Pretrial Services Agency as an indication of the defendant's status with respect to those factors whose consideration is mandated by items ii and iii. It is true that a defendant who was employed or had some but not all possible community ties might not receive a favorable recommendation, but, generally speaking, the judge had no way of knowing this. Also a defendant tied to the community in only one way but with all other factors favorable might be recommended for ROR. Importantly, the variablerecommended for release-is not so much a proxy for the defendant's actual community ties as it is for the judge's perception of such ties.

Item $i v$ addresses the question of the defendant's prior criminal record. Data on prior arrests, as well as misdemeanor and felony convictions, were included.

Item $v$ mandates consideration of prior records or failures to appear or flight to avoid prosecution. Information was not routinely presented on this issue despite its seeming relevance to the likelihood of subsequent court appearances. ${ }^{24}$

Item $v i$ mandates consideration of the strength of the evidence. The assumption is that the greater the likelihood of a conviction with its accompanying penalty, the greater the incentive to flee. The records available to me contained no information on the strength of the evidence, but the judges were similarly in the dark. They usually made pretrial release decisions before probable cause hearings were held, and evidentiary matters were rarely alluded to in the bail hearings. ${ }^{25}$

Item vii prescribes consideration of the sentence that may be imposed upon conviction. Since the New York Penal Code

24 In a study of pretrial outcomes for federal defendants, where data for prior record of flight are systematically available, I find that contrary to my expectations, a prior failure to appear does not substantially affect the restrictiveness of the conditions of pretrial release (see Stryker et al., 1983). This finding is interpreted as support for the thesis that judges are not determining pretrial release outcomes solely on the basis of whether the defendant is likely to appear.

25 My analyses are based on the initial pretrial release decision made following arrest. Some defendants had subsequent pretrial hearings following their probable cause hearing. In these cases, it may be that more evidentiary material was considered. I note too that when questions of the strength of the evidence were raised at the initial pretrial release hearing, the issue was often raised in the following manner: The judge would ask the Assistant District Attorney to comment, without supporting materials, on the strength of the case. 
NAGEL

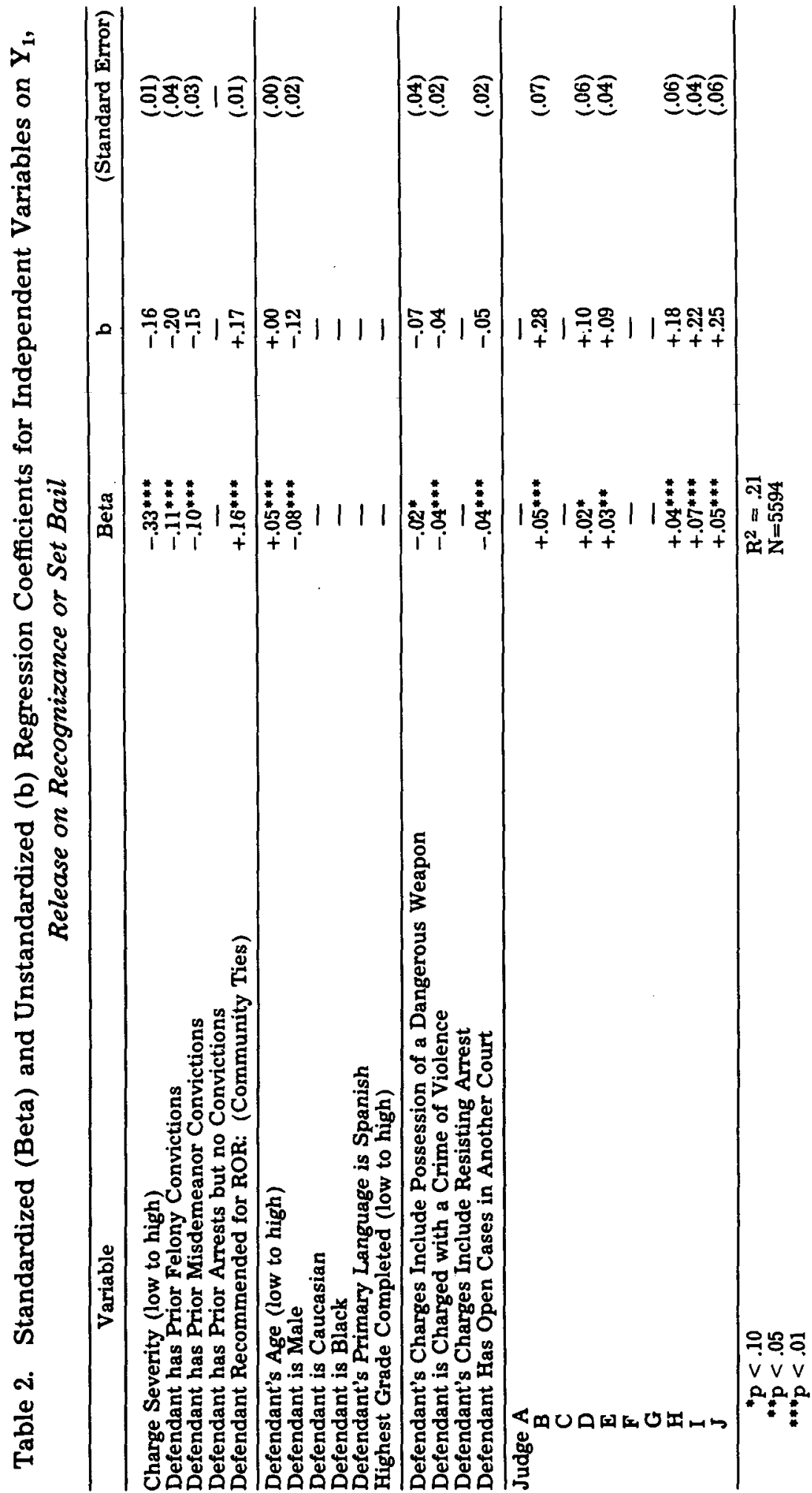


links the severity of the offense (e.g., A, B felony) to the maximum sentence, I treat charge severity as a measure of this consideration. ${ }^{26}$

To summarize, my interpretation of the statutory prescriptions suggests that the following variables may be classifled as legal: the statutory severity of offenses for which defendants are charged, their prior criminal records, and the recommendations of the Pretrial Services Agency. I am unable to measure other variables, such as evidentiary strength and financial resources, but am comforted by the fact that judges too appeared to know little of such matters. The other variables included in Table 1 , such as sex, age, ethnicity, and the identity of the judge, are for reasons mentioned earlier classifled as extra-legal.

Turning to Table 2 and the decision whether to release a defendant on recognizance $\left(Y_{1}\right)$, we find that those variables which reflect factors mentioned in the Bail Statute significantly affect this decision. A recommendation for release by the Pretrial Services Agency is positively associated with the decision to release on recognizance, while charge severity and prior convictions for both misdemeanors and felonies have the expected negative association. While legal factors are not the only ones significantly associated with the release decision, one can safely conclude that they are important to this first pretrial release decision. Regressing $Y_{1}$ on the legal variables alone tells us that by themselves, but not discounting variance shared with extra-legal variables, they explain 19 percent of the variance. ${ }^{27}$ The total explained variance for $Y_{1}$ by legal and extra-legal variables is 21 .

An examination of Table 3 , in which the amount of set bail $\left(Y_{2}\right)$ is the dependent variable, reveals a somewhat different

26 One can argue that sentence severity relates to both the lawful purpose of predicting appearance and the unlawful purpose of predicting new crime. Thus, sentence severity is a measure of potential danger as well as risk of appearance. There is no way to separate the two ways in which sentence severity may relate to decisions for pretrial release.

27 This figure refers to the gross effect of the legal variables. In a recent article (see Stryker et al., 1983), using data on pretrial release decisions for federal defendants, I present gross and net effects for sets of variables including those that tap ascribed status characteristics of the defendant, achieved status characteristics of the defendant, characteristics of the offense charged, characteristics associated with the act of being processed in the criminal justice system, and characteristics of the organizational context in which the defendant is prosecuted. In a separate article (Nagel et al., 1983) on judicial compliance with the Federal Bail Reform Act, I compute gross and net effects for a more complete list of legal and extra-legal variables. Importantly, while each of the analytic strategies differs slightly, the pattern is consistent: legal variables significantly affect pretrial release decision outcomes. 
NAGEL $\quad 499$

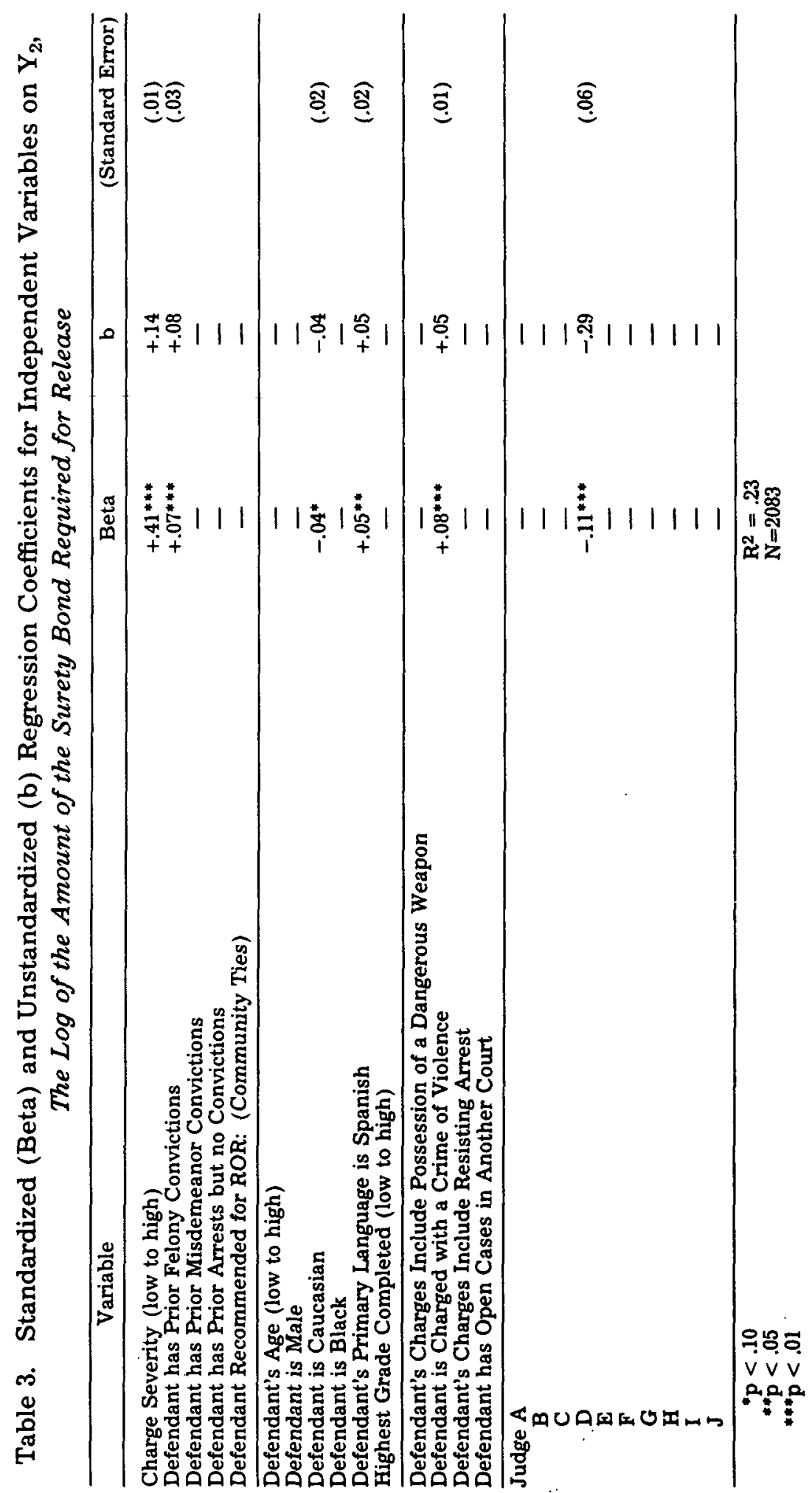




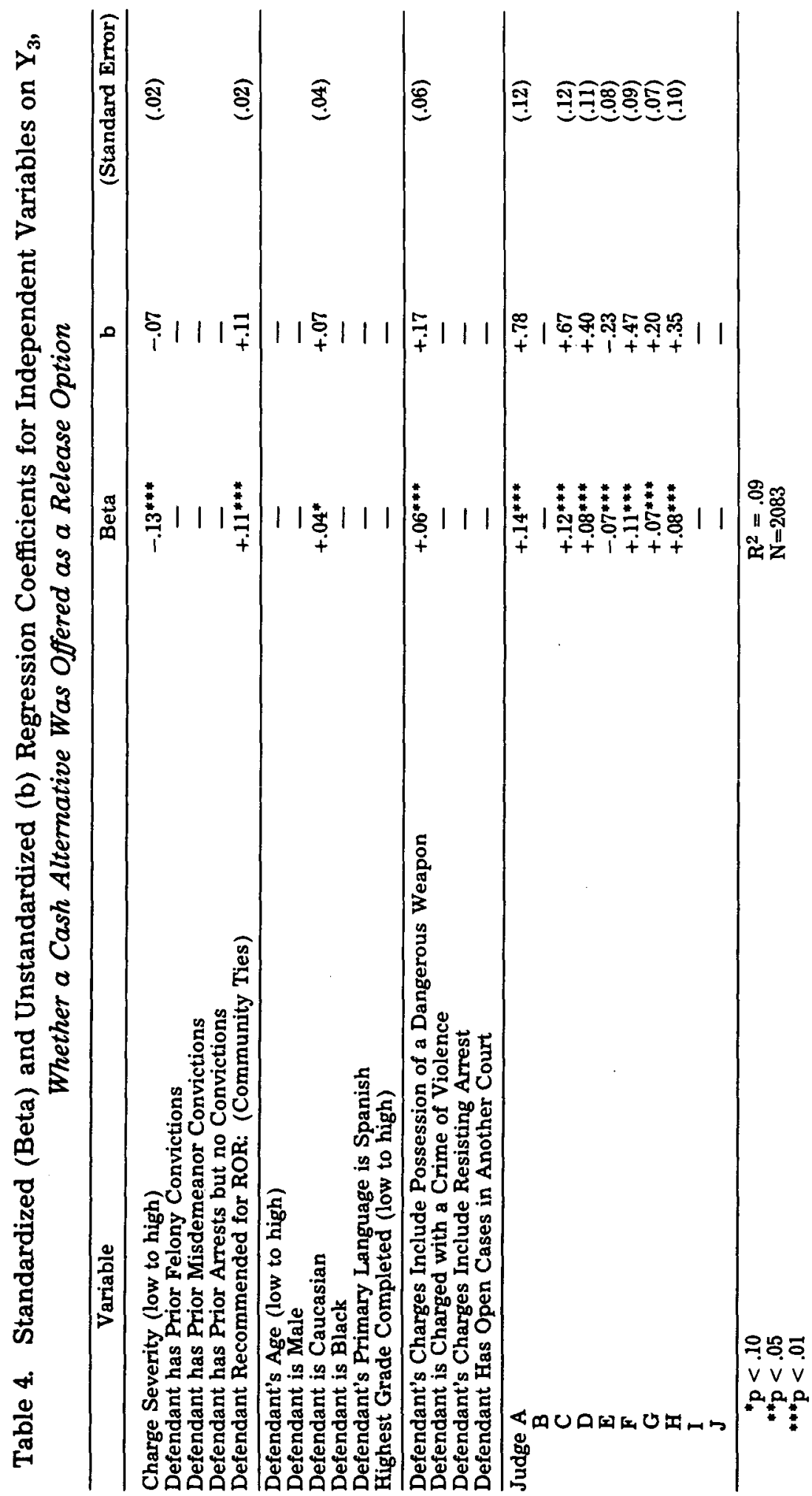


pattern. Neither the release recommendation of the Pretrial Agency nor recorded misdemeanor convictions have a statistically significant impact on this decision. But charge severity and recorded felony convictions continue to affect the decision in the expected direction. The relative importance of charge severity is particularly striking. It is largely because of its impact that the configuration of "legal" variables explains, not discounting the variance shared with extra-legal variables, 21 percent of the variance in bail amount. The total variance explained with legal and extra-legal variables included is .23.

Finally, turning to Table 4, in which the decision to offer a cash alternative $\left(\mathrm{Y}_{3}\right)$ is the dependent variable, we find yet another pattern of results. Convictions drop out of the picture entirely, while the recommendation for release by the Pretrial Services Agency is once again significantly associated with a judicial decision in the predicted direction. Charge severity continues to have its predicted impact. This time, as expected, it is negatively associated with the probability of being offered a cash alternative. Looking at the equation as a whole, one notes that the total explained variance is substantially less than it was when either the release on recognizance or amount of bail decisions were dependent variables. The legal variables as a block, not discounting for variance shared with the extralegal variables, explain 5 percent of the variance in the decision to offer a cash alternative. The legal and extra-legal variables together explain only 9 percent of the variance.

In considering the influence of legal factors on pretrial release decisions, one should recall the statutory language:

... In determining that matter [the kind and degree of control or restriction that is necessary to secure an accused's court attendance], the court must, on the basis of available information, consider and take into account ...

While the statute requires the court to consider the factors specified, there is ambiguity in the phrase "available information," and it is unclear how a court should act in the absence of information. If by "available information" what is meant is that a court must consider information which is available because it is introduced at the arraignment hearing, there is no normative implication when a court does not consider factors, such as the weight of the evidence or the defendant's financial circumstances, about which it is seldom informed. If, however, the statutory reference to "available information" carries with it an expectation that such information will systematically be sought and presented, then 
blame for the failure to provide information on all of the statutorily prescribed factors can be assigned either to the Pretrial Services Agency as the watchdog agency or to the attorneys who represent the state and the defendants. Alternatively, depending upon one's view of the boundaries of judicial responsibility, one might blame the judiciary for their failure to insist on the availability of all relevant information before making pretrial release decisions. Regardless of whether and to whom one assigns blame, it is clear that some legal factors have no influence not because of judicial resistance but because information is not available.

It also appears from these analyses that where information on statutorily prescribed factors is available, the information affects pretrial release decisions in the way the legislature intended. Thus, enacted law affects law in action.

\section{B. Are the Effects of Statutorily Prescribed Factors Constant Across the Three Decisions?}

As has already been seen, the effects of the factors mentioned in the Bail Statute vary with the type of decisions. (See also Goldkamp, 1979.) Perhaps the most striking difference is the effect of the Pretrial Services Agency's recommendation for release. This probably reflects the fact that community ties, measures of which dominate the Agency's checklist, is a recent addition to the legislature's list of factors that courts should consult in making pretrial release decisions. The decision to weight community ties heavily in bail decisions reflects in part the recognition that a system dependent upon a defendant's economic resources to purchase his pretrial liberty discriminates against the indigent (Ares et al., 1963; Dill, 1972). It also reflects highly publicized research which showed that defendants with substantial community ties were, if released on their own recognizance, more likely to appear at trial than defendants who were less well integrated into the community but could make bail. Thus, the movement to make community ties an important factor in bail decisions was, at the outset, both ideologically and empirically associated with the movement to release more defendants on their own recognizance. Indeed, to this day the Pretrial Agency's recommendation addresses primarily the release on recognizance decision. In light of this, it is not surprising to find that the Pretrial Services Agency recommendation is the second most salient predictor of the decision to release on recognizance. 
It is somewhat surprising that the Pretrial Agency recommendation has no statistically significant impact on the amount of bail requested if bail is set (see Table 3). For the cash alternative decision (see Table 4), however, the Pretrial Agency recommendation affects the outcome decision in much the same way as it affects the initial release decision, although it is less important than the identity of certain judges. Here I can only speculate, but it appears that the decision to offer a cash alternative is a decision to allow a costless release in much the same way as the decision to release on recognizance. Defendants offered a cash alternative need not find a willing bail bondsman, and if they show up at trial, their money is refunded. It may be that judges who feel they must set bail despite the Pretrial Agency's recommendation for release compromise and allow a cash alternative in such cases. In this connection it is interesting to note that judges $\mathrm{A}, \mathrm{C}$, and F-the three judges whose presence on the bench is most strongly associated with the decision to offer a cash alternative in Table 4 -are three of the four judges whose presence on the bench is not significantly associated with the decision to release on recognizance. This suggests that some judges may regard the cash alternative as an alternative to release on recognizance and so offer cash alternatives in situations (e.g., when there are favorable Agency reports) where other judges would release without bail.

The effect of sentence exposure, as measured by charge severity, also varies depending upon the decision context, as does the effect of the prior criminal record. Charge severity is the most salient of the independent variables for the first two decisions, but when the cash alternative is the dependent variable, its magnitude is less, as is its salience relative to the other variables. Similarly, the influence of a defendant's prior criminal convictions is substantial for the first two decisions and absent for the third decision. This may be because each of these variables, although legal, also reflects danger, a factor that is not to be considered in setting bail except in extraordinary circumstances. I cannot separate out the extent to which these variables have the influence the legislature intended from the extent to which they encourage judges to engage in preventive detention. If the latter influence exists, it may be that it plays itself out in the decisions to deny release on recognizance and set particularly high bail. From a preventive detention' standpoint, if high bail has been set, the apparent concession of the cash alternative may not matter. 
It appears from these analyses that legal factors are somewhat less important to the cash alternative decision than they are to the initial release decision and the decision on bail amount. This may be because the cash alternative is a recent and, for this reason, an unfamiliar option in New York bail procedures (Thomas, 1976). Also, judges may not be sure whether the factors that the Bail Statute prescribes for consideration are meant to apply to the cash alternative decision. The statute reads as follows:

.. . To the extent that the issuance of an order of recognizance or bail and the terms thereof ... the following factors ... (510.30 §1)

If the cash alternative is regarded as an alternative to a bail bond, and thus not part of the terms thereof, the statute, if interpreted literally, does not apply, and judges have no statutory guidance in deciding whether to offer a cash alternative. Finally, there may be a statistical problem here. The decision to offer a cash alternative may interact with the decision on bail amount. The model presented here is not sensitive to such interaction.

The fact that the Pretrial Services Agency's recommendation is important to the release on recognizance decision but not to the decision on bail amount may be attributable to the way in which the Agency presents its information to the judge. It recommends release on recognizance or it issues no recommendation, but in neither case does it systematically give the judge information on the specific factors (e.g., the defendant's employment, family ties, and length of residence in the community) that have determined its stance. The Agency's report takes no position on the amount at which bail should be set should the judge decide to set bail. Thus, although the Pretrial Agency's recommendation is based on measures of community ties and other factors that should, according to the statute, influence both the release on recognizance and terms (i.e., bail amount) decisions, the Agency casts its recommendation in a form that addresses only the release on recognizance question. It is possible that if the Agency gave the judge its detailed information on the factors, such as community ties, that influence its decision, the judge would, in accordance with the statutory scheme, weigh such information in deciding on the amount of bail. It is also possible that these factors would only influence the bail amount decision, or would have their greatest impact on that decision, if the Agency translated the factor 
scores into recommendations for specific bail amounts should bail be set. For it is possible that in the release decision the judge who follows the Agency recommendation is influenced as much by the suggestion of shared responsibility as he is by his knowledge that the Agency recommendation reflects the accused's community ties.

Looking separately at the three stages of the bail decision process does not resolve all the questions raised regarding the influence of legal variables, but it does emphasize the importance of examining the impact of legal factors in a variety of decision contexts. Had I looked only at the release on recognizance decision, I might have thought legal factors dominated. Had I looked only at the bail amount decision, I would have thought that legal factors were less central and community ties, in particular, of no importance. The actual situation is more complicated and more interesting.

\section{Do Factors Not Prescribed in the Statute Affect Pretrial Release Decisions?}

A review of the effects of age, sex, race, language, education, the nature of the crime(s) charged, the presence of open cases, and particular judges shows that each of the three pretrial release decisions is affected by factors that are not statutorily prescribed. The pattern of results leads to three conclusions. First, to the extent that "extra-legal" is defined as that which is not prescribed in the formal law, I find support for the thesis that judicial decisions are influenced by a host of extra-legal factors.

Second, the extra-legal factors most commonly emphasized in the literature, e.g., age, race, sex, and social class, do not predominate. They are not the most salient of the nonstatutorily prescribed factors affecting pretrial release decisions, nor do their effects exceed those of the more important statutorily prescribed factors, e.g., charge severity. Education, which is as close as I can come in this relatively homogeneous sample to a measure of social class, is nowhere significant. $^{28}$ The same is basically true for the age of the defendant. The defendant's sex is significant for the first decision-males are 12 percent less likely to be released on recognizance than are females-but not for the latter two. This is consistent with other research on criminal justice outcomes

28 I have not directly measured social class because this population of defendants, like many drawn from state court data, has little variation on this dimension. Education, however, does have reasonable variability. 
(Nagel and Hagan, 1982b). The defendant's race has no effect on the decision to release on recognizance and small effects on the bail amount decision and on the decision to offer a cash alternative. ${ }^{29}$ While the effect is small, it is in the direction predicted-bail tends to be lower for whites, and they are more likely to be offered the cash alternative option. In short, neither the labeling nor the conflict theory approach finds much support in these data. In this jurisdiction, for this sample during the period studied age, race, sex, and education predict poorly to pretrial release decisions.

Third, the effect of factors not statutorily prescribed varies across the three decisions. The importance of contextual variation is underscored for extra-legal factors as it was for legal factors.

\section{What Kinds of Biases Are Suggested by Those Factors Not Prescribed in the Statute Which Affect Pretrial Release Decisions?}

Here I want to distinguish between what I call bench bias and social bias. Social biases are the kinds of biases discussed in the preceding section. Bench bias refers to the tendency of particular judges to prefer some kinds of outcomes to others regardless of case characteristics. The law's norms do not as an ideal allow for either type of bias-decisions should be affected by, and should only be affected by, legally relevant case characteristics. However, as a normative matter the two types of bias have different implications. Social biases involve consistent discrimination for or against a class of people (e.g., blacks, women, the elderly). Bench bias, as Lawrence Friedman points out (1977: 65-66), is with respect to other bases of social classification essentially random..$^{30}$ It is luck rather than some personal characteristic that determines whether one's case will be heard by a "hanging" judge.

Bench bias has a statistically significant effect on all three decisions, but it is of considerable importance only when the issue is whether to offer a cash alternative. Looking first at the

29 In an analysis not reported here I further subdivide this sample into serious felonies and less serious felonies and misdemeanors. The significant effects of race (blacks tend to face higher bonds if bail is set, and Caucasians are more likely to be offered a cash alternative) are of low relative importance and confined to the most serious felonies. A copy of the tables breaking the analysis down by charge seriousness is available from the author.

30 Bench biases may interact with social biases. For example, other things being equal, Judge $X$ may be especially likely to demand high bail of black defendants. He may treat white defendants in the same way other judges do. 
decision to release on recognizance and using the conservative measure of the unique increment which judicial identity makes to the total amount of explained variance (what psychologists call "usefulness"), I find a net incremental increase in explained variance of only .008 , but this is significant at the .01 level. Looking at Table 2, I note that some judges, e.g., Judge B, Judge I, Judge $\mathrm{J}$, are, in comparison with their brethren, particularly likely to release defendants on their own recognizance.

When bail amount $\left(Y_{2}\right)$ is the dependent variable, bench bias appears to be confined to Judge $D$, who is exceptionally lenient in setting bail. It is some measure of the importance of a single judge that the information on judicial identity adds a unique contribution of .013 to the total explained variance. This is significant at the .01 level.

With respect to the first two dependent variables, bench bias mattered but not very much. When the question is whether to offer a cash alternative, bench bias is overwhelming. The $R^{2}$ without consideration of the variation explained by judges is .05 . The net increment added by introducing judges into the equation is .04 . For the cash alternative decision, judicial identity appears to have about as much explanatory power as the legal variables and other extra-legal variables combined. This suggests that, at least in the early days of the cash alternative option, decisions regarding it were largely a matter of judicial taste.

Lawyers, on the basis of their day-to-day experience, have long propounded the thesis that the fate of defendants at pretrial depends on the judge before whom they appear. The results reported here confirm this observation but only to a limited extent. The importance of the judge factor depends on the decision in question. While the judge's identity is generally of importance to the release on recognizance decision, its importance is dwarfed by other factors. Furthermore, an analysis not presented reveals that the influence of judicial identity is largely confined to defendants charged with misdemeanors and the less serious felonies. Where defendants charged with serious felonies are considered, only one judge, Judge $\mathrm{J}$, is significantly different from his fellows. When it comes to setting bail, most judges are not discernibly different, but because of the presence of one exceptionally lenient judge, a defendant can get very lucky. ${ }^{31}$ In the decision on whether to

31 The conclusion that the judges in my study show no differences in their decisions on bail amount must be tempered by the recognition of a selection 
offer a cash alternative, the influence of the individual judge is paramount among factors associated with the outcome.

For most persons, especially those interested in the plausibility of conflict or labeling theories, the more critical question is whether the influence of extra-legal factors is interpretable as a social bias which results in discrimination against the underprivileged classes of society. I have already concluded that the view that age, race, sex, and education are primary determinants of pretrial release outcomes is not substantiated by these data, although some evidence of social biases exists. Whites had somewhat lower bail than blacks or Hispanics, and they were slightly more likely to be offered a cash alternative. Also, those whose primary language is Spanish fared slightly worse than English speakers on the bail amount decision. However, while these effects are statistically significant, they are neither more salient than the legal factors, nor are they generally more substantial than other extra-legal factors. In short, I have identified indicators of the three determinants of pretrial release decisions that are not prescribed in the statute. These extra-legal influences are bench bias, social bias, and a judicial concern for dangerousness.

\section{Determining Release on Recognizance}

While bench bias and social biases relating to age and sex influence the decision whether to release on recognizance, there is no clear course of redress or reform. To eliminate bench bias, one would have to further standardize decisions. The history of bail is replete with criticism of bail schedules (see, for example, Freed and Wald, 1964). The Federal Bail Reform Act, and the New York Bail Law modeled after it, were passed, in part, to attenuate the relationship between the charged offense and bail decisions, to reflect the degree to which community ties predict to later court appearance, and to encourage individualized decisions through discretion structured by the factors prescribed in the statute. To recommend increased standardization would be to recommend a return to a system that has proved unsatisfactory.

bias problem. Some judges were more liberal than others in releasing defendants on their own recognizance. Thus, the defendants they set bail for are likely, as a group, to be less attractive on variables I was unable to measure than the defendants encountered by those who were not particularly likely to release on recognizance. A similar pattern of bail setting controlling for measured variables could, were everything in fact held constant, reflect a tendency by judges who were liberal in releasing on recognizance to set somewhat lower bail amounts. 
Apart from these variables there is only one other way in which the factors that influence the ROR decision depart from the statute's normative model. Defendants charged with violent offenses (e.g., murder, arson, rape) are less likely to be released on recognizance than those charged with less violent crimes of equal statutory severity. An analysis not reported shows this effect to be confined to the most serious statutory felonies. ${ }^{32}$ Since the violence of the offense is related to danger to the community, and not to the risk of appearance, and there is no statutory authority to consider dangerousness (see People v. Welch; People ex rel. Shaw v. Lombard), this suggests that extra-legal factors have some inappropriate influence. But this judgment is clouded by the fact that New York case law allows remand without bail in cases of extreme dangerousness. The fact that the association between the violent nature of the crime charged and the decision not to release on recognizance is significant only in the case of serious felonies and is, in fact, reversed in the case of less serious felonies and misdemeanors is at least consistent with the claim that the consideration of dangerousness is responsive to what the law allows.

To the extent that dangerousness is a consideration in cases less extreme than those the case law contemplates, Friedman probably identifies the root of this influence when he writes:

Scholars who study how judges decide cases have spent enormous amounts of time and energy studying legal variables, role variables, attitude variables, value variables, background variables, socio-economic variables, and so on. They have spent surprisingly little time and effort on another factor, which may be the strongest of all: the pressure of outside force, of public opinion, in short, of the world in which the judges live (1977: 109).

\section{Determining the Amount of Set Bail}

The decision concerning bail amount $\left(\mathrm{Y}_{2}\right)$ is affected by fewer legal and extra-legal factors than is the release decision $\left(Y_{1}\right)$. Yet, the amount of explained variance is almost identical (for $Y_{1}$, the $R^{2}=.21$; for $Y_{2}$, the $R^{2}=.23$ ). The determination of the bail amount seems most responsive to the severity of the crime charged and the defendant's prior criminal record. These are legal variables, but they may influence the judge in part

32 Those charged with violent misdemeanors or less serious felonies are actually somewhat more likely to receive a release on recognizance if statutory seriousness is held constant. 
because of what they suggest about dangerousness. There is some evidence of social bias, bench bias, albeit limited to one judge, and bias introduced by the consideration of whether the charged offense is a crime of violence. As with the release decision, the last is only important when serious felonies are charged. Two of these three raise important policy questions. The evidence of some discrimination, however small, in favor of whites (as compared to blacks and Hispanics) and against those whose primary language is Spanish suggests that discrimination against the socially disadvantaged is still a problem with which to wrestle. The evidence of a premium charged for serious, but not the less serious, crimes of violence raises the question of whether the money bail system allows the cosmetic fixing of high bail to accomplish the unlawful purpose of preventive detention.

\section{Determining the Cash Alternative Offer}

The decision to offer a cash alternative is most distinctive for its unpredictability. The amount of explained variance $\left(\mathrm{R}^{2}=.09\right)$ is low and borders on the vanishing point when judicial identity is not considered. The impact of individual judges is remarkable. For example, holding constant the legal variables and extra-legal variables I have considered, appearing before Judge A brings with it a probability of being offered a cash alternative that is 78 percent higher than the average. Conversely, appearance before Judge $\mathbf{E}$ carries with it a probability of a cash alternative that is 23 percent below the average. This study suggests that the cash alternative decision is in its determinants unlike the decision to release or the determination of the amount of bail. While there is a suggestion in the data that some judges may use the cash alternative as an alternative to release on recognizance (e.g., Judge $E$ is 9 percent above the average in his willingness to release on recognizance while Judge A's behavior does not differ significantly from the average), the evidence is too sparse to warrant any conclusions. Future research should seek to determine whether such a substitution effect exists or whether the decision is a random reflection of judicial tastes. No matter what the findings, we must learn more about how this pattern has come to be in order to address intelligently the policy questions that arise. 


\section{CONCLUSIONS}

I began with a set of research questions, all of which are relevant to the legal/extra-legal controversy. I was interested in exploring in a preliminary way whether factors specifically prescribed for consideration in the Bail Statute affected pretrial release decisions and whether their impact varied with the particular pretrial release decision at issue. To the extent that factors not specifically prescribed by the statute were influencing pretrial release decisions, I was interested in discerning whether such effects were suggestive of bench bias or of more systematic discrimination against the socially disadvantaged. The analyses suggest several conclusions that are of general importance in socio-legal research.

First, the hypothesis that formal law is but one entry into the decision calculus of those given responsibility for the application of law is supported. If one takes, as I have here, the category of "legal factors" in the legal/extra-legal debate to be coextensive with what is defined in the formal written law (e.g., statutes), my results are consistent with the longstanding argument of interaction theorists who study societal responses to deviants (e.g., Becker, 1963; Kitsuse and Circourel, 1963; Goode, 1975). There is a less than perfect correspondence between the formal law and its application. More specifically, these findings can be said to be consistent with the hypothesis of legal realists (e.g., Fuller, 1934; Llewellyn, 1930; 1962) that legal rules are but one consideration in judicial decisions. The findings strongly suggest, however, that legally specified criteria play a role and often a dominant role in such decisions. This suggests that attempts to document the impact of extralegal factors on legal decisions will, if they do not adequately measure legal factors, present a misleading picture. This is not just because extra-legal variables will be spuriously significant (see, e.g., Hagan, 1974). It is also the case that if influential legal variables are excluded from our models, there will be a distorted picture of both the relative importance of extra-legal variables and the legality of judicial decision-making in general. One implication is that sociologists of the law must be able to work with legal source material as well as empirical data.

Second, and perhaps more interesting, is that the saliency of the role of statutorily prescribed factors varies across decisions. This finding underscores the importance of context in research of this kind. One implication is that the presumption that societal responses to deviants, court responses to defendants, or judicial decisions can be explained 
by one overarching theoretical model is likely to prove untenable. Research examining the multitude of decisions that surround each type and stage of decision seems necessary if we are to understand what is going on. Studies of sentencing decisions might, for example, reveal more if they focused separately on the decision whether to incarcerate, the choice of non-custodial sentences (e.g., fine and probation), and the length of custodial sentences (e.g., jail or prison time) in the appropriate subsamples (see, for example, Wheeler et al., 1982; Nagel and Hagan, 1982a; Hagan and Nagel, 1982). My expectation is that the influence of statutorily prescribed factors, as well as non-statutorily prescribed (what I have called "extra-legal") factors, will vary across these decision contexts.

Third, my findings suggest that it is useful to separate the effects of statutorily prescribed (legal) factors from those suggestive of bench bias, social bias, and other influences. By so doing, one may gain insight into the conditions under which racial and other forms of discrimination are more or less pronounced, as well as a more realistic estimate of the bias introduced by inter-judge variation and some sense of the conditions under which extra-legal factors compete with or even exceed the impact of statutorily prescribed factors.

Fourth, I argued in my introductory remarks that one should not assume that certain factors are or are not legal. Law in the books, as law in theory is sometimes termed, is what the written laws, as modified by court decisions, actually state (Weber, 1954). It may be discovered in the law library without benefit of the sociological imagination. Where the law has been codified, the legal/extra-legal controversy can best be explored by the simultaneous consideration of statutorily and nonstatutorily prescribed factors. Even in this instance, however, case law should be examined to check for judicial amendments.

Race, age, sex, and other demographic measures are clearly not the only extra-legal factors that can influence judicial decisions, even though research influenced by conflict and labeling theories appears most concerned with such variables. In the case of pretrial release decisions, the extra-legal factors seemingly most determinative of pretrial release decisions are the perceived likelihood that the defendant would be dangerous if freed and the identities of the individual judges. The New York Bail Statute does not authorize the judge to consider danger in deciding whether to release the defendant or in determining the amount of bail. New York case law 
glosses the statute by allowing remand without bail where the defendant is thought to pose an extreme danger and seems to say that likely dangerousness may not be considered if the danger is not extreme or in setting the amount of bail if remand without bail is not justified. However, but for the case law, it would be incorrect to call the consideration of danger in situations where it is not extreme "illegal." Illegal seems to imply that the formal law prohibits its consideration. The New York Bail Statute does not say directly that danger shall not be considered and is ambiguous about whether the criteria it lists are meant to be exclusive. The question of justice is a philosophical and moral issue which is not easily resolved. This brings me to my final point.

I believe that the distinction among the kinds of factors that have extra-legal effects is the key to drawing policy implications from court outcome research. To the extent that race or ethnic discrimination can be identified as being pronounced in a particular decision context or associated with a particular outcome, such as the cosmetic fixing of high bail, modes of redress can be explored and suggested. To the extent that predictions of dangerousness are influential in spite of the law, one can call for reform to handle, on the one hand, society's real concern for danger, and on the other hand, the protection of defendants from inappropriate over-predictions. And to the extent that the law compounds the effects of previous discrimination, which it may by authorizing a judge to consider a defendant's prior record (where prior record can be shown to be unrelated to the risk of appearance), one can suggest that the law be changed accordingly.

The legal/extra-legal controversy has for too long dictated a model of research that has failed to give due weight to either side of the debate. The complexities of law have often been ignored, and the extra-legal category has been narrowly and selectively defined. My research suggests that both components should be refined and reexamined as part of the continuing process that seeks to understand the bases for the decisions that lead to court outcomes.

\section{REFERENCES}

AMERICAN BAR ASSOCIATION (1978) Pretrial Release. American Bar Association Standards Relating to the Administration of Criminal Justice. Washington, D.C.: American Bar Association. 
ARES, C., A. RANKIN and H. STURZ (1963) "The Manhattan Bail Project: An Interim Report on the Use of Pretrial Parole," 38 New York University Law Review 67.

BECKER, Howard E. (1963) Outsiders: Studies in the Sociology of Deviance. New York: Free Press.

BERNSTEIN, Ilene Nagel, William KELLY and Patricia DOYLE (1977a) "Societal Reaction to Deviants: The Case of Criminal Defendants," 42 American Sociological Review 743.

BERNSTEIN, llene Nagel, Edward KICK, Jan LETNG and Barbara SCHULZ (1977b) "Charge Reduction: An Intermediary Stage in the Process of Labelling Criminal Defendants," 56 Social Forces 362.

BLACK, Donald (1971) "The Social Organization of Arrest," 23 Stanford Law Review 1087.

BURKE, Peter and Austin TURK (1975) "Factors Affecting Postarrest Dispositions: A Model for Analysis," 22 Social Problems 313.

CARBONE, June (1977) "The Evolution of Standards for Bail Decisions." Unpublished paper, Yale University Law School.

CHAMBLISS, William J. and Robert B. SEIDMAN (1971) Law, Order and Power. Reading: Addison-Wesley.

CHIRICOS, Theodore G. and Gordon P. WALDO (1975) "Socioeconomic Status and Criminal Sentencing: An Empirical Assessment of a Conflict Proposition," 40 American Sociological Review 753.

DIL, Forest (1972) "Bail and Bail Reform: A Sociological Study." Unpublished Ph.D. Dissertation, University of California, Berkeley.

FEDERAL BAIL PROCEDURES (1964) Hearings Before the Committee on the Judiciary. 88th Congress.

- (1981) Bills to Amend the Bail Reform Act of 1966. 97th Congress.

FREED, Daniel and Patricia WALD (1964) Bail in the United States. Washington, D.C.: United States Department of Justice and Vera Foundation.

FRIEDMAN, Lawrence M. (1977) Law and Society. Englewood Cliffs, N.J.: Prentice-Hall.

FULLER, Lon L. (1934) “American Legal Realism," 82 University of Pennsylvania Law Review 429.

GOLDBERGER, Arthur (1964) Econometric Theory. New York: Wiley.

GOLDKAMP, John S. (1979) Two Classes of Accused. Cambridge, MA. Ballinger.

GOODE, Erich (1975) “On Behalf of Labelling Theory," 22 Social Problems 57.

HAGAN, John L. (1974) "Extra-Legal Attributes and Criminal Sentencing: An Assessment of a Sociological Viewpoint," 8 Law \& Society Review 357.

- (1975) "Parameters of Criminal Prosecution: An Application of Path Analysis to a Problem of Criminal Justice," 65 Journal of Criminal Law and Criminology 536.

HAGAN, John and Ilene H. NAGEL (1982) "White Collar Crime/White Collar Time: The Sentencing of White Collar Offenders in the Southern District of New York," 20 American Criminal Law Review 259.

HAGAN, John, Mene NAGEL and Celesta ALBONETTI (1980) "The Differential Sentencing of White-Collar Offenders in Ten Federal District Courts," 45 American Sociological Review 802.

KENNEDY, Edward (1979) "Address of Senator Kennedy to the National Governors Conference on Crime Control." Washington, D.C.: Office of Senator Edward M. Kennedy.

KERLINGER, Fred and Elazor PEDHAZUR (1973) Multiple Regression in Behavioral Research. New York: Holt, Rinehart, and Winston.

KITSUSE, John and Aaron CICOUREL (1963) "A Note on the Uses of Offlial Statistics," 11 Social Problems 131.

LaFREE, Gary (1980) "The Effect of Sexual Stratiflcation by Race on Official Reactions to Rape," 45 American Sociological Review 842.

LANDES, William (1974) "Legality and Reality: Some Evidence of Criminal Procedure," 4 Journal of Legal Studies 287.

LEMERT, Edwin (1951) Social Pathology. New York: McGraw-Hill.

LIZOTTE, Alan (1978) "Extra-Legal Factors in Chicago's Criminal Courts: Testing the Conflict Model of Criminal Justice," 25 Social Problems 564.

LLEWELLYN, Karl (1930) The Bramble Bush 3.

(1962) "A Realistic Jurisprudence-The Next Step," Jurisprudence 3 (See Bechtler, Thomas W. [1977] Law in a Social Context. The Netherlands: Kluwer.) 
McBARNET, Doreen (1981) Conviction: Law, the State and the Construction of Justice. London: Macmillan.

MLLER, F.W. (1970) Prosecution: The Decision to Charge a Suspect With a Crime. Boston: Little, Brown.

NAGEL, Ilene H. and John HAGAN (1982a) "The Sentencing of White-Collar Criminals in Federal District Court: A Socio-Legal Exploration of Disparity," 80 Michigan Law Review 1427.

- (1982b) "Gender and Crime: Offense Patterns and Criminal Court Sanctions," in N. Morris and M. Tonry (eds.), Crime and Justice: An Annual Review of Research, Vol. IV. Chicago: University of Chicago Press.

NAGEL, Ilene H., John HAGAN and Liese SHERWOOD-FABRE (1983) "Judicial Compliance With the Federal Bail Reform Act." Unpublished manuscript, Indiana University School of Law.

QUINNEY, Richard (1970) The Social Reality of Crime. Boston: Little, Brown.

REISS, Albert J. (1974) "Discretionary Justice," in D. Glasner (ed.), Handbook of Criminology. Chicago: Rand MeNally.

SCHRAG, Clarence (1971) "Crime and Justice: American Style, Crime and Delinquency Issues." Washington, D.C.: NIMH Monograph Series \#HSM 729052 .

STRYKER, Robin, Dene H. NAGEL and John HAGAN (1983) "Methodological Issues in Criminal Court Research: Pretrial Release Decisions for Federal Defendants," 11 Sociological Methods and Research 469.

SUDNOW, David (1965) "Normal Crime: Sociological Features of the Penal Code in a Public Defender Office," 12 Social Problems 250.

SWIGERT, Victoria Lynn and Ronald A. FARRELL (1977) "Normal Homicides and the Law," 43 American Sociological Review 16.

THOMAS, Wayne (1976) Bail Reform in America. Berkeley, CA.: University of California Press.

UNNEVER, James, Charles FRAZIER and John HENRETTA (1980) "A Race Difference in Criminal Sentencing," 21 Sociological Quarterly 197.

WEBER, Max (1954) Max Weber on Law and Economy and Society. Ed. Max Rheinstein. Cambridge, MA.: Harvard University Press.

WHEELER, Stanton, David WEISBURD and Nancy BODE (1982) "Sentencing the White-Collar Offender," 47 American Sociological Review 641.

WOLFGANG, Marvin and Mark RIEDEL (1973) "Race, Judicial Discretion, and the Death Penalty," 407 The Annals of the American Academy of Political and Social Science 119.

\section{CASES CITED}

Carlson v. Landon, 342 U.S. 524 at 545, 1952.

People ex rel. Klein v. Krueger, 25 N.Y. 2nd 497, 307 N.Y.S. 2nd 207, 255 N.E. 2nd 552, 1969.

People ex rel. Schweizer v. Welch, 336 N.Y.S. 2nd 556, 1972.

People ex rel. Shapiro v. Keeper of City Prison et al., 290 N.Y. 393, 398, 49 N.E. 2nd 498, 500, 1943.

People ex rel. Shaw v. Lombard, 408 N.Y.S. 2nd 664, 1978.

People v. Melville, 308 N.Y.S. 2nd 671, 1970.

People v. Torres, 446 N.Y.S. 2nd 969, 1981.

\section{STATUTES CITED}

N.Y.S. RULES OF CRIMINAL PROCEDURE, 510.30 \$ 1-2. 
